\title{
Minimum forest cover required for sustainable water flow regulation of a watershed: a case study in Jambi Province, Indonesia
}

\author{
Suria Tarigan ${ }^{1}$, Kerstin Wiegand ${ }^{2}$, Sunarti ${ }^{3}$, and Bejo Slamet ${ }^{4}$ \\ ${ }^{1}$ Department of Soil Sciences and Natural Resource Management, Bogor Agricultural University, Bogor, Indonesia \\ ${ }^{2}$ Department of Ecosystem Modeling, University of Göttingen, Büsgenweg 4, 37077 Göttingen, Germany \\ ${ }^{3}$ Faculty of Agriculture, University of Jambi, Jambi, Indonesia \\ ${ }^{4}$ Faculty of Agriculture, North Sumatra University, Medan, Indonesia
}

Correspondence: Suria Tarigan (sdtarigan@apps.ipb.ac.id)

Received: 1 March 2017 - Discussion started: 29 May 2017

Revised: 15 October 2017 - Accepted: 7 December 2017 - Published: 24 January 2018

\begin{abstract}
In many tropical regions, the rapid expansion of monoculture plantations has led to a sharp decline in forest cover, potentially degrading the ability of watersheds to regulate water flow. Therefore, regional planners need to determine the minimum proportion of forest cover that is required to support adequate ecosystem services in these watersheds. However, to date, there has been little research on this issue, particularly in tropical areas where monoculture plantations are expanding at an alarming rate. Therefore, in this study, we investigated the influence of forest cover and oil palm (Elaeis guineensis) and rubber (Hevea brasiliensis) plantations on the partitioning of rainfall into direct runoff and subsurface flow in a humid, tropical watershed in Jambi Province, Indonesia. To do this, we simulated streamflow with a calibrated Soil and Water Assessment Tool (SWAT) model and observed several watersheds to derive the direct runoff coefficient $(C)$ and baseflow index (BFI). The model had a strong performance, with Nash-Sutcliffe efficiency values of 0.80 0.88 (calibration) and $0.80-0.85$ (validation) and percent bias values of $-2.9-1.2$ (calibration) and 7.0-11.9 (validation). We found that the percentage of forest cover in a watershed was significantly negatively correlated with $C$ and significantly positively correlated with BFI, whereas the rubber and oil palm plantation cover showed the opposite pattern. Our findings also suggested that at least $30 \%$ of the forest cover was required in the study area for sustainable ecosystem services. This study provides new adjusted crop parameter values for monoculture plantations, particularly those that control surface runoff and baseflow processes, and it also de-
\end{abstract}

scribes the quantitative association between forest cover and flow indicators in a watershed, which will help regional planners in determining the minimum proportion of forest and the maximum proportion of plantation to ensure that a watershed can provide adequate ecosystem services.

\section{Introduction}

In recent years, monoculture plantations have rapidly expanded in Southeast Asia, and the areas under oil palm (Elaeis guineensis) and rubber (Hevea brasiliensis) plantations are expected to increase further (Fox et al., 2012; Van der Laan et al., 2016). In Indonesia, which is currently the largest palm oil producer worldwide, the oil palm plantation area increased from $7000 \mathrm{~km}^{2}$ in 1990 to $110000 \mathrm{~km}^{2}$ in 2015 (Ditjenbun, 2015; Tarigan et al., 2016b), and a further $170000-200000 \mathrm{~km}^{2}$ is projected for future oil palm development (Colchester et al., 2006; Wicke et al., 2011; Afriyanti et al., 2016). This rapid expansion of oil palm plantations has been partly triggered by an increased demand for biofuel production (Mukherjee and Sovacoo, 2014). In addition, rubber plantations, which are also prevalent in Southeast Asia (Ziegler et al., 2009), currently cover $35000 \mathrm{~km}^{2}$ of land in Indonesia (Ditjenbun, 2015).

Although oil palm is of economic value to farmers and the local regions in which it is grown, it has received environmental and social criticism, often being held responsible for 
deforestation (Wicke et al., 2011; Vijay et al., 2016; Gatto et al., 2017), biodiversity loss (Fitzherbert et al., 2008; Koh and Wilcove, 2008; Wilcove and Koh, 2010; Carlson et al., 2012; Krashevska et al., 2015), decreased soil carbon stocks (Guillaume et al., 2015, 2016; Pransiska et al., 2016), and increased greenhouse gas emissions (Allen et al., 2015; Hassler et al., 2017). Similarly, rubber plantations have environmental impacts such as reducing the soil infiltration capacity, accelerating soil erosion, increasing stream sediment loads (Ziegler et al., 2009; Tarigan et al., 2016b), and decreasing soil carbon stocks (Ziegler et al., 2011). Furthermore, the conversion of tropical rainforest into oil palm and rubber plantations affects the local hydrological cycle by increasing transpiration (Ziegler et al., 2009; Sterling et al., 2012; Röll et al., 2015; Hardanto et al., 2017), increasing evapotranspiration (ET) (Meijide et al., 2017), decreasing infiltration (Banabas et al., 2008; Tarigan et al., 2016b), increasing the flooding frequency (Tarigan, 2016a), and decreasing low flow levels (Yusop et al., 2007; Adnan and Atkinson, 2011; Comte et al., 2012; Merten et al., 2016). These climatic impacts that occur due to land use change are expected to be stronger under maritime conditions, such as those in Indonesia, than under continental conditions because $40 \%$ of the global tropical latent heating of the upper troposphere occurs over the maritime continent (Van der Molen et al., 2006).

The forests in Jambi Province, Indonesia, have been largely transformed into plantations (Drescher et al., 2016), resulting in inhabitants experiencing water shortages during the dry season and a dramatic increase in flooding frequency during the wet season (Merten et al., 2016; Tarigan, 2016a) because plantations promote higher levels of direct runoff than forested lands (Bruijnzeel, 1989, 2004; Tarigan et al., 2016b; Dislich et al., 2017). However, this negative impact of plantation expansion could be minimized by maintaining an adequate proportion of forested land as a watershed, which raises the following question: what is the minimum proportion of forest cover that is required in a watershed to support adequate water flow regulation?

The water flow regulation function of watersheds represents their ability to retain rainwater and is one of the most important soil hydrological processes in tropical regions where rainfall is highly seasonal (Lele, 2009). Functional water flow regulation by a watershed reduces flood peaks by moderating direct runoff (Le Maitre et al., 2014; Ellison et al., 2017) via soil water infiltration through the soil surface and percolation through the soil profile. This vertical movement of water through the soil determines how much water flows as direct runoffs and how much reaches the water table where it is sustained as baseflow or groundwater (Hewlett and Hibbert, 1967; Bruijnzeel, 1990; Le Maitre et al., 2014; Tarigan et al., 2016b). Forest vegetation provides organic matter and habitat for soil organisms, thereby facilitating higher levels of infiltration than other land uses (Hewlett and Hibbert, 1967).
A number of empirically based and process-based approaches can be used for assessing the impacts of expanding rubber and oil palm plantations on hydrological characteristics in the Southeast Asia region. Empirically based approaches use long-term historical data to correlate land use changes with corresponding streamflow data (Adnan and Atkinson, 2011; Rientjes et al., 2011; Mwangi et al., 2016) or paired catchment studies (Bosch and Hewlett, 1982; Brown et al., 2005), whereas process-based approaches use physically based hydrological models in which the impact of land use changes is determined by varying the land use/cover settings (Khoi and Suetsugi, 2014; Guo et al., 2016; Zhang et al., 2016; Marhaento et al., 2017; Wangpimool et al., 2017). Process-based approaches have the drawback of requiring more data to be input and having high uncertainty in parameter estimation (Xu et al., 2014; Zhang et al., 2016). However, there is currently an absence of long-term historical data for Jambi Province, precluding the use of an empirically based approach.

Distributed hydrological models are useful for understanding the effects of land use changes on watershed flow regulation. One such model is the Soil and Water Assessment Tool (SWAT) ecohydrological model (2012), which quantifies the water balance of a watershed on a daily basis (Neitsch et al., 2011) and has been recommended for evaluating the hydrological ecosystem services of a watershed (Vigerstol and Aukema, 2011). The SWAT model approach is one of the most widely used and scientifically accepted tools for assessing water management in a watershed (Gassman et al., 2007). Consequently, its popularity has also increased in Southeast Asia. Marhaento et al. (2017) recently used the SWAT model to analyze the impact of forest cover and agriculture land use on the runoff coefficient $(C)$ and baseflow index (BFI) on Java Island, Indonesia, and found that a decrease in forest cover from 48.7 to $16.9 \%$ and an increase in agriculture area from 39.2 to $45.4 \%$ increased $C$ from 35.7 to $44.6 \%$ and decreased BFI from 40 to $31.1 \%$. Meanwhile, Wangpimool et al. (2017) found that the expansion of rubber plantations in Thailand between 2002 and 2009 led to an annual reduction of approximately $3 \%$ in the average water yield of the basin, whereas Babel et al. (2011) found that the expansion of oil palm plantations in Thailand increased nitrate loading $(1.3-51.7 \%)$ in the surface water based on SWAT simulations. Tarigan et al. (2016b) also used the SWAT model to simulate the impact of soil and water conservation practices on low flow levels in oil-palm-dominated watersheds in Jambi Province, Indonesia. This study aimed to quantify the minimum proportion of forest cover that is required to allow a watershed to provide adequate ecosystem services. We selected Jambi Province as our study area because of the rapid expansion of oil palm and rubber plantations in that area. The study findings provide new adjusted values for crop parameters of monoculture plantations, particularly those that control surface runoff and baseflow processes, and they describe the quantitative association between forest cover and flow in- 


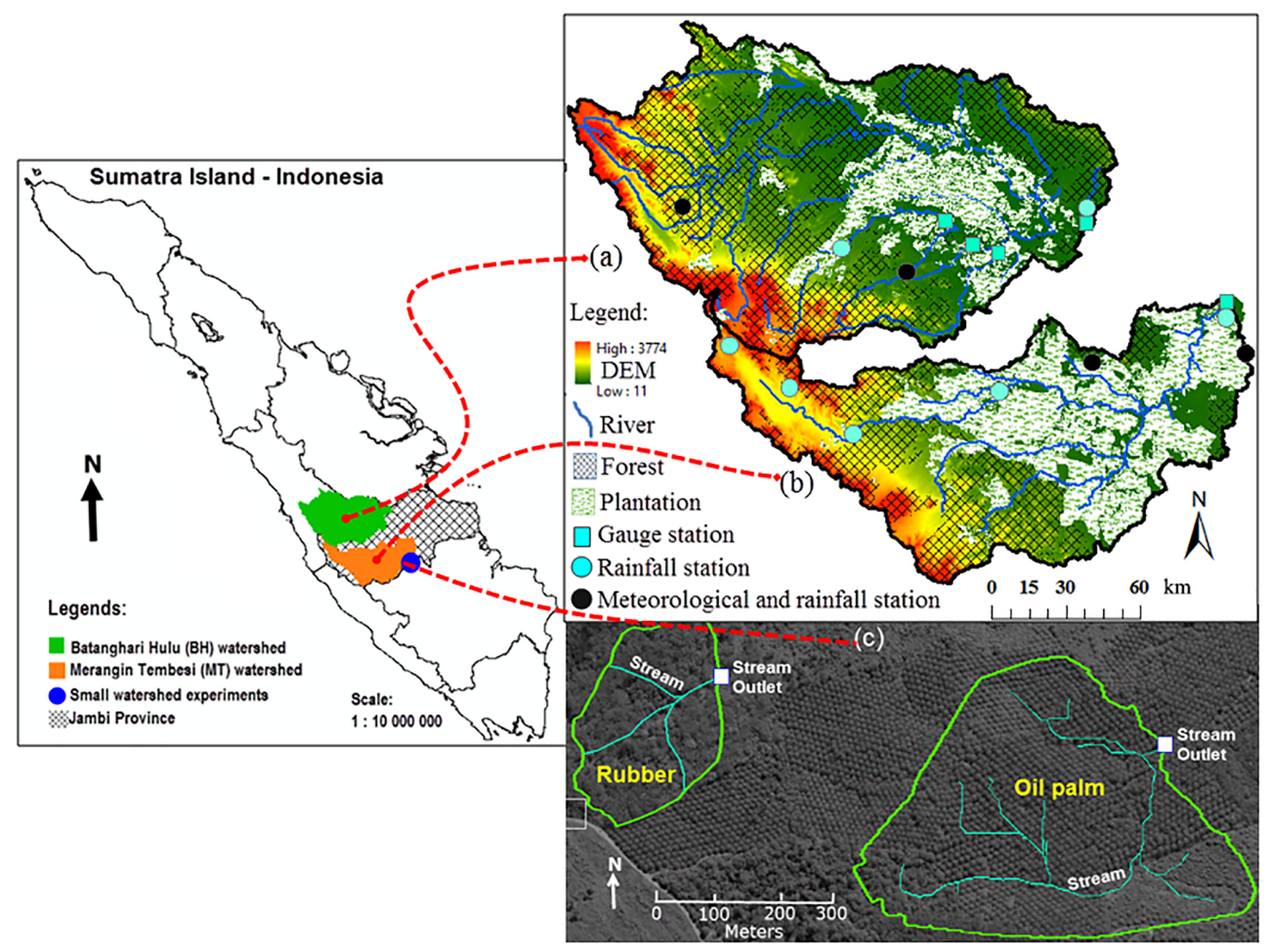

Figure 1. Locations of the (a, b) macro and (c) small watershed experiments in Jambi Province, Sumatra, Indonesia.

dicators in a watershed, which will help regional planners in determining the minimum proportion of forest that needs to be conserved to ensure that a watershed can provide adequate ecosystem services.

\section{Methods}

\subsection{Study area}

The study area is located in Jambi Province, Sumatra $\left(1^{\circ} 54^{\prime} 31.4^{\prime \prime} \mathrm{S}, 103^{\circ} 16^{\prime} 7.9^{\prime \prime} \mathrm{E}\right.$; Fig. 1). There has been a rapid expansion of plantations in this area, particularly oil palm and rubber (Drescher et al., 2016). The area has a tropical humid climate, with an average temperature of $27^{\circ} \mathrm{C}$ and an average rainfall of $2700 \mathrm{~mm} \mathrm{yr}^{-1}$. The rainy season occurs from October to March. The area under oil palm plantation in the study area (Jambi Province) increased from $1500 \mathrm{~km}^{2}$ in 1996 to $6000 \mathrm{~km}^{2}$ in 2011, representing an almost $400 \%$ increase (Setiadi et al., 2011), whereas the area under rubber plantation increased from 5000 to $6500 \mathrm{~km}^{2}$ over the same period (Ditjenbun, 2015). In 2013, only $30 \%$ of Jambi Province was covered with rainforest (mainly located in mountainous regions), with $55 \%$ of the land having been converted into agricultural land, of which $10 \%$ was degraded/fallow and will potentially be converted into monoculture plantations (Drescher et al., 2016).
The study area consists of two macro watersheds for the simulation of the $C$ and BFI values with the SWAT model, namely Batanghari Hulu (BH; Fig. 1a) and Merangin Tembesi (MT; Fig. 1b) watersheds, which cover areas of 18415 and $13452 \mathrm{~km}^{2}$, respectively. The dominant land uses in both watersheds are forest $(\mathrm{BH}, 50 \%$; MT, 30\%) and plantation (BH, $18 \%$; MT, $48 \%$ ). The dominate soil types in the study area are classified as Tropodult and Dystropept, which are characterized as consisting of medium to heavy texture (Allen et al., 2015).

To ensure that the $C$ and BFI values obtained from the macro watershed simulations (particularly those subwatersheds that were dominated by oil palm or rubber) reflected the real observed values in the field, we carried out the direct $C$ measurements in two small watersheds, with sizes of 14 and 9 ha, respectively, in the study area (Fig. 1c). These small watersheds were covered with $90 \%$ oil palm and $80 \%$ rubber plantations, respectively.

Oil palm and rubber are perennial crops that have a life cycle of 25 years. Both crops are planted in rows at planting distances of 8 and $4 \mathrm{~m}$, respectively. In oil palm plantations, there are two types of paths between the planting rows: the harvest path, which is used to transport freshly harvested fruit bunches, and the so-called death path, which is used for piling pruned leaf fronds, which occupy approximately $2 \mathrm{~m}$ or one-quarter of this path. Both oil palm and rubber require very intensive harvesting activities, which occur twice per month for oil palm and almost daily for rubber; thus, soils 
Table 1. Water storage capacity of the leaf axils along the trunks of oil palm trees.

\begin{tabular}{lrrrr}
\hline \multirow{2}{*}{ Replicate } & \multicolumn{4}{c}{ Water storage (mm) } \\
\cline { 2 - 5 } & Tree 1 & Tree 2 & Tree 3 & Tree 4 \\
\hline 1 & 14.2 & 10.8 & 4.4 & 6.2 \\
2 & 10.6 & 10.2 & 4.2 & 5.9 \\
3 & 9.4 & 10.5 & 5.9 & 7.9 \\
4 & 8.1 & 10.4 & 5.4 & 7.4 \\
5 & 8.8 & 11.5 & 3.8 & 9.8 \\
6 & 9.4 & 10.9 & 6.0 & 8.0 \\
7 & 9.3 & 10.6 & 5.9 & 7.5 \\
8 & 10.1 & 11.0 & 5.2 & 7.3 \\
9 & 8.9 & 11.2 & 4.7 & 10.5 \\
10 & 9.5 & 11.3 & 4.9 & 7.2 \\
\hline \multicolumn{5}{c}{ Average $=8.4 \mathrm{~mm}$}
\end{tabular}

along the harvest path and part of the death path are very compacted. The soils under oil palm and rubber plantations remain unploughed for the entire growing period. Weeds in the oil palm plantations are regularly eradicated using herbicides or mechanical equipment. Intensive inorganic fertilization (1000 $\left.\mathrm{kg} \mathrm{ha}^{-1} \mathrm{yr}^{-1}\right)$ also occurs, contributing to the degradation of the soil structure and fauna.

\subsection{SWAT model}

The SWAT model is a continuous long-term yield model that was developed to simulate the impact of different land cover/management practices on streamflow in complex watersheds with varying soil, land use, and management conditions over long time periods. The major model components include weather, hydrology, soil temperature, soil properties, plant growth, nutrients, and land management (Neitsch et al., 2011; Arnold et al., 2012).

During the modeling process, a watershed is subdivided into several sub-watersheds, which are then further partitioned into hydrological response units (HRUs) that are defined by their topography, soil, and land use characteristics, which are not spatially referenced in the model. The hydrological outputs of HRUs are calculated using the water balance equation and include total streamflow, surface flow, and baseflow. These output components can then be used to calculate indicators of the water flow regulation functions of a watershed, namely $C$, which is the ratio of direct runoff to rainfall, and BFI, which is the proportion of baseflow in the streamflow.

Because the SWAT model was designed for temperate regions, adapting crop parameter inputs for use in tropical regions is necessary (Strauch et al., 2013; Van Griensven et al., 2014; Alemayehu et al., 2017). To avoid incorrect parameterization of sensitive values, we carried out field measurements for interception, infiltration, and surface runoff to adapt the parameter values, particularly those that control

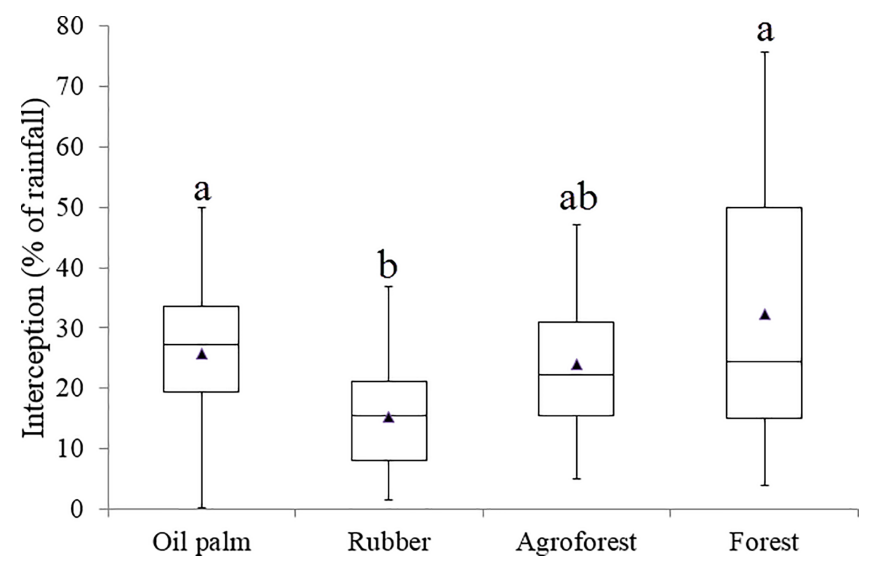

Figure 2. Canopy interception of rainfall under different land uses. Different letters indicate significant differences between the means (Bonferroni-corrected post hoc $t$-test based on analysis of variance (ANOVA); $p<0.05$ ).

surface runoff and baseflow processes. We then performed SWAT model simulation in two study watersheds and conducted small watershed experiments to compare the observed $C$ values with those obtained from simulations.

\subsubsection{Model setup}

Delineation of watersheds and their sub-watersheds in our study area was automatically performed by the SWAT model and was based on a digital elevation model (DEM) with a $30 \mathrm{~m}$ resolution. During this automatic delineation, we predefined 50000 ha as a threshold for the minimum subwatershed area, based on subdivision of the BH and MT watersheds into 25 and 23 sub-watersheds, respectively.

\section{Crop parameters}

Oil palm plantations exhibit specific characteristics, particularly with respect to rainfall partitioning. These characteristics include high interception, high ET, low soil infiltration, high proportion of surface runoff, and absence of leaf litter, of which the first four can potentially reduce baseflow. Therefore, to consider these specific characteristics, we conducted field measurements and adjusted several crop parameters that are related to flow components, including canopy storage (CANMX), plant uptake compensation factor (EPCO), hydrologic soil group (HSG), and Soil Conservation Service (SCS) curve number $(\mathrm{CN})$.

a. Interception. CANMX is the maximum amount of water that can be stored in the canopy and trunks of fully developed trees. Thus, an increase in this parameter reflects a reduction in the amount of rainfall that reaches the ground. In oil palms, rainfall is intercepted not only by leaves and branches but also by water reservoirs in leaf axils along the trunk. Therefore, we measured the 
Table 2. Adapted parameter inputs for the study area.

\begin{tabular}{|c|c|c|c|c|c|}
\hline SWAT parameter & Definition & Oil palm & Rubber & Agroforest & Fores \\
\hline \multirow[t]{2}{*}{ CANMX (mm) } & Maximum trunk storage & 8.4 & 0 & 0 & 0 \\
\hline & Maximum canopy storage & 4.7 & 2.7 & 4.3 & 5.8 \\
\hline HYDGRP & Hydrologic soil group & $\mathrm{D}$ & $\mathrm{D}$ & B & $\mathrm{C}$ \\
\hline $\mathrm{CN} 2$ & Curve number & 83 & 83 & 65 & 45 \\
\hline $\mathrm{SOL} \_\mathrm{BD}\left(\mathrm{g} \mathrm{cm}^{-3}\right)$ & Soil bulk density & $1.2-1.3$ & $1.2-1.3$ & 1 & 0.9 \\
\hline EPCO & Plant uptake compensation factor & 1 & 1 & 1 & 1 \\
\hline OV_N & Manning's $n$ value for overland flow & 0.07 & 0.14 & 0.4 & 0.5 \\
\hline $\mathrm{SOL} \_\mathrm{K}\left(\mathrm{mm} \mathrm{h}^{-1}\right)$ & Saturated hydraulic conductivity & 30 & 78 & 400 & 470 \\
\hline SOL_AWC $\left(\mathrm{mm} \mathrm{mm}^{-1}\right)$ & Available water capacity & 0.1 & 0.1 & 0.2 & 0.2 \\
\hline $\operatorname{BLAI}\left(\mathrm{m}^{2} \mathrm{~m}^{-2}\right)$ & Maximum potential leaf area index & $3.6^{*}$ & 2.6 & 5 & 5 \\
\hline CHTMX (m) & Maximum canopy height & 12 & 13 & 14 & 20 \\
\hline T_BASE & Base temperature & 20 & 20 & 20 & 20 \\
\hline ALPHA_BF & Baseflow recession constant & $0.90-0.95$ & $0.90-0.95$ & $0.90-0.95$ & $0.90-0.95$ \\
\hline T_OPT & Optimal temperature & 28 & 28 & 30 & 30 \\
\hline
\end{tabular}

* Fan et al. (2015)

Table 3. Model input data sources.

\begin{tabular}{|c|c|c|c|}
\hline Data type & Resolution & Description & Source \\
\hline Topography & $30 \mathrm{~m}$ & DEM with a resolution of $30 \mathrm{~m}$ per pixel & SRTM \\
\hline Soil map & $1: 250000$ & $\begin{array}{l}\text { Additional soil data were collected from } \\
\text { the field and previous studies }\end{array}$ & Soil Research Institute, Ministry of Agriculture \\
\hline Land use & $1: 100000$ & Land use map with intensive ground check & Regional Planning Office (BAPPEDA ${ }^{\mathrm{a}}$ ) \\
\hline $\begin{array}{l}\text { Rainfall } \\
\text { and climate }\end{array}$ & Daily & $\begin{array}{l}\text { Rainfall and meteorological stations at Rantau } \\
\text { Pandan, Siulak Deras, Muara Hemat, Padang } \\
\text { Aro, Depati Parbo, Bangko, Bungo, Pematang } \\
\text { Kabau, and Bungku }\end{array}$ & $\mathrm{BMKG}^{\mathrm{b}}$ office and $\mathrm{CRC} 990^{\mathrm{c}}$ \\
\hline Streamflow & $\begin{array}{l}\text { Daily discharge } \\
\text { data }\end{array}$ & $\begin{array}{l}\text { Stations at Muara Tembesi, Air Gemuruh, } \\
\text { Batang Tabir, Batang Pelepat, and Muara Kilis }\end{array}$ & Ministry of Public Works (BBWS ${ }^{\mathrm{d}}$ ) \\
\hline
\end{tabular}

a BAPPEDA, Regional Planning Office (Badan Perencanaan Daerah). ${ }^{\mathrm{b}}$ BMKG, Meteorology, Climatology and Geophysics Agency (Badan Meteorologi, Klimatologi dan Geofisika). ${ }^{\mathrm{c}}$ CRC990, Collaborative Research Centre $990 .{ }^{\mathrm{d}}$ BBWS, Ministry of Public Works (Balai Besar Wilayah Sungai).

water storage capacity of leaf axils along the trunks of four 10-12-year-old oil palm trees with 10 replications per tree. We found that the leaf axils along the trunk can store up to $20 \mathrm{~L}$ or $8.4 \mathrm{~mm}$ of water (Table 1 ), which matches previous reports that the leaf axils along oil palm trunks have a high water storage capacity (Merten et al., 2016; Meijide et al., 2017).

We also measured the canopy interception by oil palm, rubber, agroforest, and forest canopies between November 2012 and February 2013. Rainfall interception was assessed by measuring throughfall and stemflow and subtracting these from the incident rainfall. In total, there were 30 rainfall events during this time, representing light to heavy rain. We found that oil palm plantations tended to exhibit higher levels of canopy interception (Fig. 2), with our estimates falling within the range of values that were previously reported for tropical forests in Southeast Asia (commonly 10-30\%; Ku- magai et al., 2005; Dietz et al., 2006). These interception assessments were used to adjust the CANMX parameter of the SWAT model (Table 2).

b. ET. Actual ET was determined by measuring the daily depletion of soil moisture content at a distance of $2 \mathrm{~m}$ from the trunks of oil palm trees. Soil moisture measurements were made on consecutive no-rain days over the 16-day period from 25 July to 10 August 2012. On average, soil moisture decreased by $6 \%$ (vol) over this period, which is equivalent to $72 \mathrm{~mm}$ or $4.5 \mathrm{~mm} \mathrm{day}^{-1}$ and is relatively high compared with the average land use in the study area. Similarly, Meijide et al. (2017) also reported a yearly oil palm ET of $1216 \mathrm{~mm}\left(4.7 \mathrm{~mm} \mathrm{day}^{-1}\right)$ using Eddy covariance measurements in the study area. This ET rate is similar to or even higher than ET rates for forests in Southeast Asia (Kumagai et al., 2005), despite oil palm having a much lower stand density and 
Table 4. The percentage of land use types, $C$, and BFI in each subwatershed within the $\mathrm{BH}$ and MT watersheds.

\begin{tabular}{|c|c|c|c|c|c|c|c|}
\hline \multirow[b]{2}{*}{ Sub-wat. no. } & \multicolumn{5}{|c|}{ Percentage of land use types } & \multirow[b]{2}{*}{$C$} & \multirow[b]{2}{*}{ BFI } \\
\hline & $\mathrm{F}$ & $\mathrm{AF}$ & $\mathrm{RP}$ & $\mathrm{OP}$ & $\mathrm{S}$ & & \\
\hline & \multicolumn{7}{|c|}{$\mathrm{BH}$ watershed } \\
\hline 1 & 56 & 0 & 17 & 0 & 26 & 0.21 & 0.71 \\
\hline 2 & 46 & 0 & 26 & 0 & 26 & 0.27 & 0.63 \\
\hline 3 & 90 & 0 & 0 & 0 & 0 & 0.00 & 0.99 \\
\hline 4 & 76 & 0 & 0 & 0 & 0 & 0.18 & 0.75 \\
\hline 5 & 16 & 0 & 67 & 0 & 17 & 0.40 & 0.32 \\
\hline 6 & 0 & 0 & 67 & 0 & 34 & 0.41 & 0.23 \\
\hline 7 & 68 & 0 & 0 & 0 & 19 & 0.17 & 0.76 \\
\hline 8 & 100 & 0 & 0 & 0 & 0 & 0.01 & 0.98 \\
\hline 9 & 80 & 0 & 0 & 0 & 0 & 0.15 & 0.79 \\
\hline 11 & 55 & 0 & 0 & 0 & 0 & 0.31 & 0.57 \\
\hline 12 & 61 & 0 & 23 & 0 & 0 & 0.23 & 0.62 \\
\hline 13 & 30 & 0 & 41 & 0 & 18 & 0.32 & 0.42 \\
\hline 14 & 84 & 0 & 0 & 0 & 16 & 0.04 & 0.91 \\
\hline 15 & 49 & 0 & 0 & 0 & 0 & 0.31 & 0.58 \\
\hline 16 & 0 & 20 & 39 & 0 & 24 & 0.36 & 0.35 \\
\hline 17 & 59 & 0 & 0 & 0 & 24 & 0.16 & 0.71 \\
\hline 18 & 0 & 0 & 82 & 19 & 0 & 0.48 & 0.03 \\
\hline 19 & 19 & 30 & 0 & 0 & 52 & 0.13 & 0.75 \\
\hline 20 & 69 & 0 & 0 & 0 & 0 & 0.22 & 0.69 \\
\hline 21 & 45 & 24 & 0 & 0 & 32 & 0.08 & 0.87 \\
\hline 22 & 0 & 26 & 16 & 58 & 0 & 0.35 & 0.28 \\
\hline 23 & 0 & 48 & 33 & 0 & 20 & 0.23 & 0.61 \\
\hline 24 & 66 & 5 & 25 & 5 & 0 & 0.14 & 0.76 \\
\hline \multirow[t]{2}{*}{25} & 44 & 32 & 0 & 7 & 17 & 0.04 & 0.93 \\
\hline & \multicolumn{7}{|c|}{ MT watershed } \\
\hline 1 & 0 & 13 & 0 & 85 & 0 & 0.59 & 0.11 \\
\hline 2 & 56 & 0 & 0 & 44 & 0 & 0.36 & 0.45 \\
\hline 3 & 0 & 16 & 0 & 82 & 0 & 0.58 & 0.13 \\
\hline 4 & 21 & 20 & 12 & 48 & 0 & 0.45 & 0.32 \\
\hline 5 & 32 & 0 & 19 & 38 & 12 & 0.40 & 0.29 \\
\hline 6 & 0 & 46 & 0 & 52 & 0 & 0.43 & 0.37 \\
\hline 8 & 0 & 0 & 15 & 86 & 0 & 0.54 & 0.01 \\
\hline 9 & 48 & 0 & 0 & 53 & 0 & 0.59 & 0.11 \\
\hline 10 & 0 & 0 & 0 & 96 & 0 & 0.34 & 0.37 \\
\hline 11 & 0 & 0 & 19 & 69 & 0 & 0.67 & 0.00 \\
\hline 12 & 0 & 0 & 13 & 88 & 0 & 0.66 & 0.01 \\
\hline 14 & 0 & 0 & 20 & 80 & 0 & 0.54 & 0.01 \\
\hline 15 & 0 & 27 & 14 & 57 & 0 & 0.65 & 0.01 \\
\hline 16 & 70 & 0 & 0 & 0 & 31 & 0.53 & 0.22 \\
\hline 17 & 0 & 28 & 11 & 57 & 0 & 0.28 & 0.65 \\
\hline 19 & 0 & 12 & 31 & 57 & 0 & 0.53 & 0.23 \\
\hline 20 & 0 & 0 & 63 & 37 & 0 & 0.60 & 0.10 \\
\hline 21 & 48 & 0 & 0 & 36 & 16 & 0.65 & 0.01 \\
\hline 22 & 36 & 0 & 17 & 17 & 16 & 0.32 & 0.42 \\
\hline 23 & 100 & 0 & 0 & 0 & 0 & 0.40 & 0.32 \\
\hline
\end{tabular}

Sub-wat. no., sub-watershed number (see Fig. 3a and b); F, forest; AF, agroforest; $\mathrm{RP}$, rubber plantation; OP, oil palm; S, shrubland. biomass per hectare. Therefore, we adjusted EPCO accordingly, which is related to ET (Table 2).

c. Infiltration and surface runoff. One important parameter of the SWAT model that is related to surface runoff is CN (Arnold et al., 2012), which determines the proportion of rainfall that becomes surface runoff (range, 0-100, with a higher value reflecting a higher level of surface runoff). The $\mathrm{CN}$ value is grouped into four HSGs (i.e., A, B, C, and D) according to the soil infiltration capacity. To adjust the $\mathrm{CN}$ value, we measured soil infiltration and surface runoff in each land use type (i.e., oil palm, rubber, agroforest, and forest) using a double-ring infiltrometer and multidivisor runoff collectors mounted at the lower end of each plot, respectively. The infiltration rate in different land use types increases in the following order: oil palm harvest path $\left(3 \mathrm{~cm} \mathrm{~h}^{-1}\right)<$ oil palm circle $\left(3 \mathrm{~cm} \mathrm{~h}^{-1}\right)<$ rubber harvest path $\left(7 \mathrm{~cm} \mathrm{~h}^{-1}\right)<$ between rubber trees $\left(7.8 \mathrm{~cm} \mathrm{~h}^{-1}\right)<$ forest $\left(47 \mathrm{~cm} \mathrm{~h}^{-1}\right)$. The infiltration rates in the oil palm and rubber plantations were markedly lower than those in the forest. Low infiltration rate in the oil palm is associated with the soil compaction due to the intensive harvest activities.

For all HRUs with oil palm and rubber land uses, we selected HSG category D (Table 2) owing to its high surface runoff and low infiltration rate. We assumed that $\mathrm{CN}$ values of the forest and agroforest were similar to those of the evergreen and mixed forest, respectively, in the SWAT crop database.

d. Litter fall. In the oil palm plantations, negligible litter was found outside the frond piles. Litter fall in oil palm plantations does not naturally occur, but leaves are cut during fruit harvest and piled up in a frond pile, which occupies only $12 \%$ of the entire oil palm plantation area. Consequently, the ground surface of oil palm plantations is managed mostly without litter, leading to higher surface runoffs. There was also negligible understory vegetation (grasses) because herbicides were routinely sprayed. The absence of the litter fall affected Manning's $n$ value for overland flow (OV_N).

e. Baseflow. The baseflow recession constant (ALPHA_BF) was calculated by plotting the selected daily streamflow hydrograph on semi-log paper and determining the average values from several individual rainfall events. A previous study (Tarigan et al., 2016b) showed a similar range of ALPHA-BF values in the study area.

\section{General input data}

The SWAT model requires considerable other types of input data in addition to the crop parameters described above, such 
Table 5. Observed $C$ values obtained from field experiments in two small watersheds that were dominated by plantation cover.

\begin{tabular}{|c|c|c|c|c|c|c|c|}
\hline \multirow[b]{2}{*}{$\begin{array}{l}\text { Event } \\
\text { no. }\end{array}$} & \multirow[b]{2}{*}{$\begin{array}{r}\text { Rainfall } \\
\left(\mathrm{cm} \mathrm{h}^{-1}\right)\end{array}$} & \multicolumn{2}{|c|}{ Rainfall volume $\left(\mathrm{m}^{3}\right)$} & \multicolumn{2}{|c|}{ Runoff $\left(\mathrm{m}^{3}\right)$} & \multicolumn{2}{|c|}{$C$ runoff coefficient } \\
\hline & & Small wat. 1 & Small wat. 2 & Small wat. 1 & Small wat. 2 & Small wat.1 & Small wat. 2 \\
\hline 1 & 6.0 & 8960 & 3136 & 4500 & 1320 & 0.50 & 0.42 \\
\hline 2 & 3.0 & 5180 & 1813 & 2625 & 840 & 0.51 & 0.46 \\
\hline 3 & 1.4 & 4095 & 1433 & 3000 & 810 & 0.73 & 0.57 \\
\hline 4 & 0.6 & 1456 & 509.6 & 1080 & 255 & 0.74 & 0.50 \\
\hline 5 & 10.7 & 14923 & 5223 & 11250 & 3900 & 0.75 & 0.75 \\
\hline 6 & 3.1 & 6006 & 2102 & 4050 & 1020 & 0.67 & 0.49 \\
\hline 7 & 2.3 & 8188 & 2885 & 6150 & 1584 & 0.75 & 0.55 \\
\hline 8 & 2.2 & 4416 & 1465 & 2400 & 780 & 0.54 & 0.53 \\
\hline 9 & 9.6 & 8916 & 3121 & 5400 & 1650 & 0.61 & 0.53 \\
\hline \multicolumn{2}{|c|}{ Average } & & & & & 0.65 & 0.53 \\
\hline \multicolumn{2}{|c|}{ Total average } & & & & & \multicolumn{2}{|c|}{0.59} \\
\hline
\end{tabular}

Table 6. Simulated $C$ values for the sub-watersheds used in the SWAT simulation (Table 4) that had similar percentages of plantation cover to the two small watersheds used in the field experiments.

\begin{tabular}{lcrc}
\hline & \multicolumn{2}{c}{ Percentage of plantation cover } & \multirow{2}{*}{$C$} \\
\cline { 2 - 3 } $\begin{array}{l}\text { Sub-wat. code } \\
\text { (see Table 4) }\end{array}$ & Oil palm & Rubber & \\
\hline BH-18 & & & \\
MT-1 & 82 & 19 & 0.49 \\
MT-8 & 85 & 0 & 0.59 \\
MT-10 & 86 & 15 & 0.54 \\
MT-11 & 96 & 0 & 0.67 \\
MT-12 & 69 & 19 & 0.67 \\
MT-14 & 88 & 13 & 0.54 \\
MT-20 & 80 & 20 & 0.65 \\
* Sub-watersheds were selected that had $>80 \%$ plantation (oil palm and \\
rubber) cover, allowing a comparison to be made with the small watersheds \\
used in the field experiment.
\end{tabular}

as the climate, topography, soil type, and land use for each sub-watershed (Table 3).

A DEM with a resolution of $30 \mathrm{~m}$ per pixel was derived from the NASA Shuttle Radar Topography Mission (SRTM). The soil map was obtained from the Soil Research Institute at a scale of $1: 250000$. Some soil parameters such as soil hydraulic conductivity, bulk density, available water content, and texture were derived from a previous study (Sunarti et al., 2008). Additional soil data were collected from Batang Tabir sub-watershed and from CRC990 plots in Bukit Duabelas and Hutan Harapan landscape (Drescher et al., 2016). Daily rainfall and climate data between 2000 and 2014 were sourced from the rainfall and meteorological stations at Rantau Pandan, Siulak Deras, Muara Hemat, Padang Aro, Depati Parbo, Bangko, Bungo, Pematang Kabau, and Bungku. Daily streamflow data between 2000 and 2014 were provided by the Ministry of Public Works (BBWS). All these data are freely available for research purposes upon official request to the corresponding institutions. The streamflow time series and rainfall records for the small catchments and the soil data have been deposited by the first author at Bogor Agricultural University and in the EFForTS Database (https://efforts-is.uni-goettingen.de). The land use for the study area was obtained from Jambi Province Regional Planning and Agricultural Plantation offices (Ditjenbun, 2015).

\subsubsection{Model validation and calibration}

The first step in the calibration and validation process in SWAT is the determination of the most sensitive parameters for a given watershed (Van Griensven et al., 2006; Arnold et al., 2012). The sensitivity analysis was performed using the SWAT Calibration and Uncertainty Procedure (SWATCUP) package, which is an interface for autocalibration that was specifically developed for SWAT and which links any calibration/uncertainty or sensitivity program to SWAT (Abbaspour, 2015).

Following the sensitivity analysis, we calibrated the SWAT model using the Latin hypercube sampling approach of the SWAT-CUP software. We first determined parameter ranges based on the minimum and maximum values allowed in SWAT. We then performed calibration and validation of the SWAT model by comparing the simulated monthly streamflows with observed data at the Muara Kilis and Muara Tembesi gauging stations from 2007 to 2009 for calibration and 2012 to 2014 for validation. Moriasi et al. $(2007,2015)$ recommended the use of three quantitative statistics for model evaluation: the Nash-Sutcliffe efficiency (NSE), percent bias (PBIAS), and the ratio of the root mean square error to the standard deviation of measured data. In this study, we used NSE and PBIAS to evaluate the model performance, which 
Table 7. Sensitivity rank and initial and final values of the calibration parameters that were used in the study for the BH and MT watersheds.

\begin{tabular}{|c|c|c|c|c|c|}
\hline \multirow[t]{2}{*}{ Parameter } & \multirow[t]{2}{*}{ Description } & \multirow{2}{*}{$\begin{array}{r}\text { Sensitivity } \\
\text { rank }\end{array}$} & \multirow{2}{*}{$\begin{array}{r}\begin{array}{r}\text { Initial value } \\
\text { range }\end{array} \\
\mathrm{BH} \text { and } \mathrm{MT}\end{array}$} & \multicolumn{2}{|c|}{ Best-fit values } \\
\hline & & & & $\mathrm{BH}$ & MT \\
\hline ALPHA_BF & Baseflow recession constant & 1 & 0.0 to 1.0 & 0.94 & 0.91 \\
\hline $\mathrm{CN} 2$ & SCS runoff curve number for moisture condition II & 2 & -0.2 to $0.2(\mathrm{~V})^{*}$ & 0.14 & 0.12 \\
\hline GW_DELAY & Groundwater delay time (days) & 3 & 30 to 450 & 62.5 & 57.2 \\
\hline CANMX & Maximum canopy storage (mm) & 4 & -0.2 to $1.0(\mathrm{~V})^{*}$ & 0.95 & 0.76 \\
\hline SOL_BD & Soil bulk density & 5 & -0.5 to $0.6(\mathrm{~V})^{*}$ & 0.46 & 0.47 \\
\hline GWQMN & $\begin{array}{l}\text { Water depth in a shallow aquifer for a return flow }(\mathrm{mm} \\
\left.\mathrm{H}_{2} \mathrm{O}\right)\end{array}$ & 6 & 0.0 to 2.0 & 0.99 & 0.95 \\
\hline SOL_K & Saturated hydraulic conductivity $\left(\mathrm{mm} \mathrm{h}^{-1}\right)$ & 7 & -0.8 to $0.8(\mathrm{~V})^{*}$ & 0.71 & 0.62 \\
\hline $\mathrm{CH} \_\mathrm{N} 2$ & Manning's $n$ value for the main channel & 8 & 0.0 to 0.3 & 0.05 & 0.15 \\
\hline SOL_AWC & $\begin{array}{l}\text { Available water capacity of the soil }\left(\mathrm{mm} \mathrm{H}_{2} \mathrm{O} \mathrm{mm}^{-1}\right. \\
\text { soil) }\end{array}$ & 9 & -0.2 to $0.4(\mathrm{~V})^{*}$ & 0.09 & 0.04 \\
\hline OV_N & Manning's $n$ value for overland flow & 10 & -0.2 to $1.0(\mathrm{~V})^{*}$ & 0.51 & 0.3 \\
\hline
\end{tabular}

$*(\mathrm{~V})=$ Variable depends on land use and soil, and so changes in calibration were expressed as a fraction.

is consistent with the majority of the existing SWAT literature (Gassman et al., 2007, 2014; Douglas-Mankin et al., 2010; Tuppad et al., 2011; Bressiani et al., 2015). NSE is a normalized statistic that determines the relative magnitude of the residual variance ("noise") compared with the measured data variance ("information") (Nash and Sutcliffe, 1970). PBIAS measures the average tendency of simulated data to be larger or smaller than that of observational data (Gupta et al., 1999), with an optimum value of zero and lower values that indicate better simulations. Positive values of PBIAS indicate model underestimation, whereas negative values indicate model overestimation.

\subsection{Simulated $C$ and BFI values and the proportion of land use types in a watershed}

The output of the validated SWAT model consisting of flow components for each sub-watershed was used to calculate indicators of the water flow regulation functions of a watershed, namely $C$, which is the ratio of direct runoff to rainfall, and BFI, which is the proportion of baseflow in the streamflow. To analyze the association between the $C$ and BFI values and the proportion of each land use type in a watershed, we derived data vectors from the BH and MT watersheds. Each of these vectors corresponded to the percentage of land use types, $C$ and BFI, in each of the 25 sub-watersheds from the $\mathrm{BH}$ watershed and 23 sub-watersheds from the MT watershed (Fig. 3a and b; Table 4).

\subsection{Measured $C$ values}

We carried out the direct $C$ measurements from the two small watersheds (Fig. 1c) between 2013 and 2015 using rectangular weirs and water level recorders for comparison with simulated $C$ values. The land use in the small watersheds is sim-

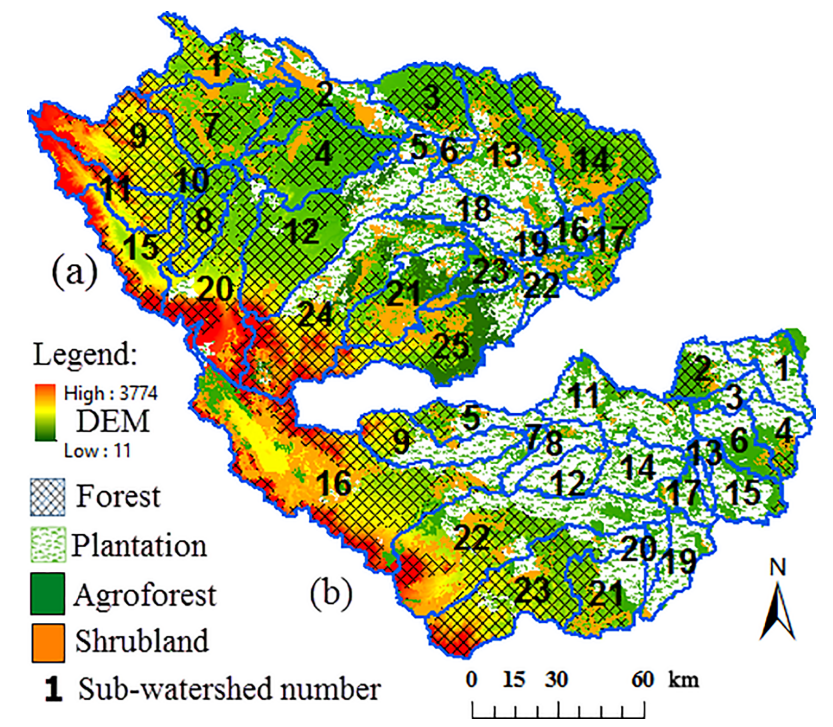

Figure 3. Land use types and sub-watershed number of the (a) $\mathrm{BH}$ and (b) MT watersheds.

ilar to the proportions found in several of the sub-watersheds shown in Table 4 (e.g., BH 18, MT 1, MT 8, MT 10, MT 11, MT 12, MT 14, and MT 20). The direct runoff components of the hydrographs were separated using the straight-line method described by Blume et al. (2007), following which $C$ was calculated. We did not calculate BFI values along with $C$ values in the small watershed experiments because BFI calculation requires hydrograph records over a longer period. 

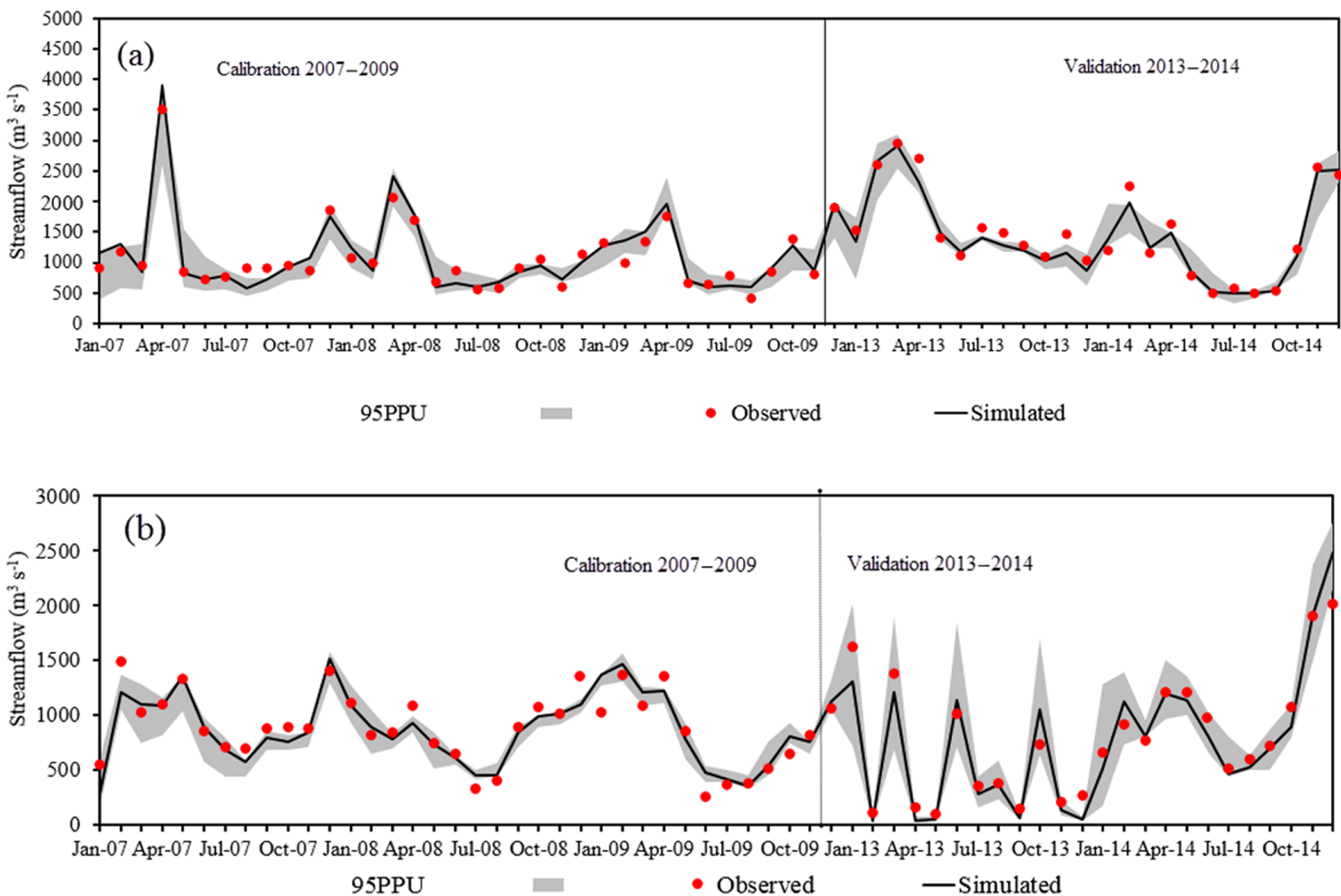

Figure 4. Observed vs. simulated streamflow and $95 \%$ uncertainty interval (95PPU; see Abbaspour, 2015) with P factors of 0.83 and 0.76 and $\mathrm{R}$ factors of 0.65 and 0.69 for the (a) BH and (b) MT watersheds, respectively.
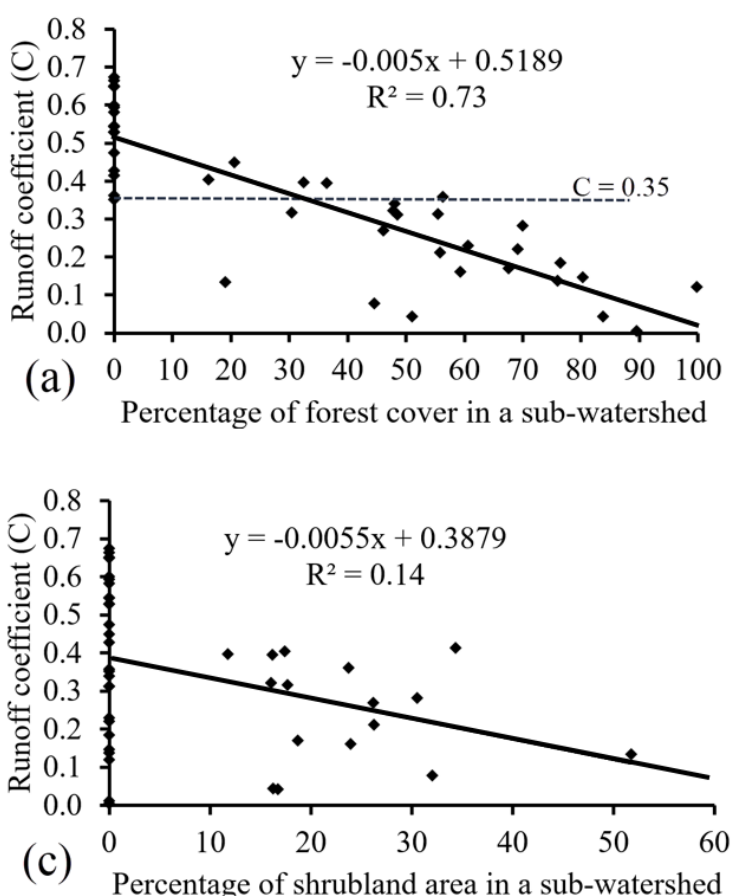
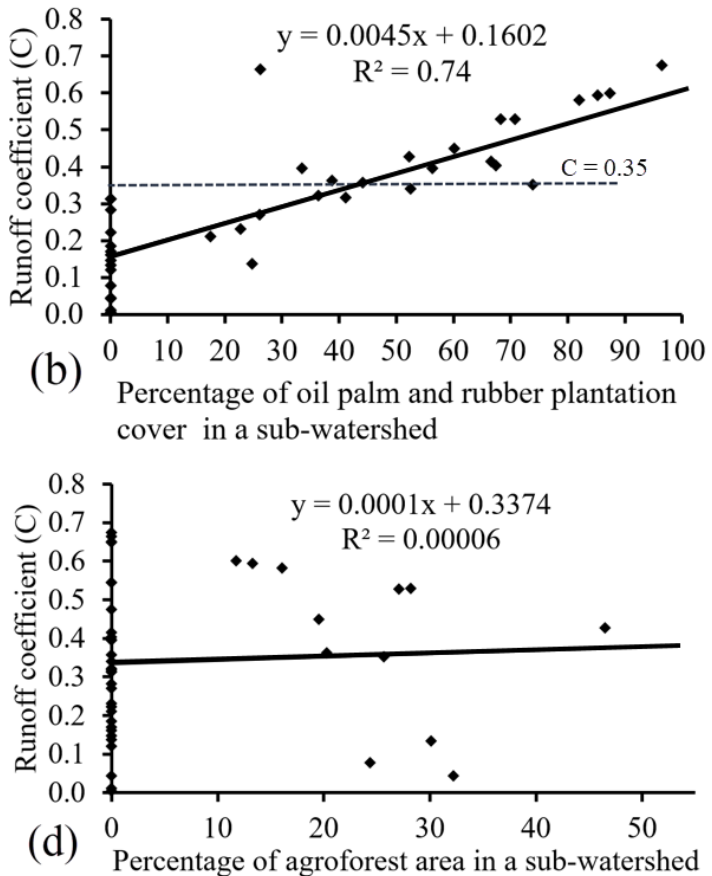

Figure 5. Association between simulated $C$ values and the percentage of each land use type in a particular sub-watershed. Dotted lines indicate the maximum acceptable $C$ value according to the Ministry of Forestry Decree (2013). 

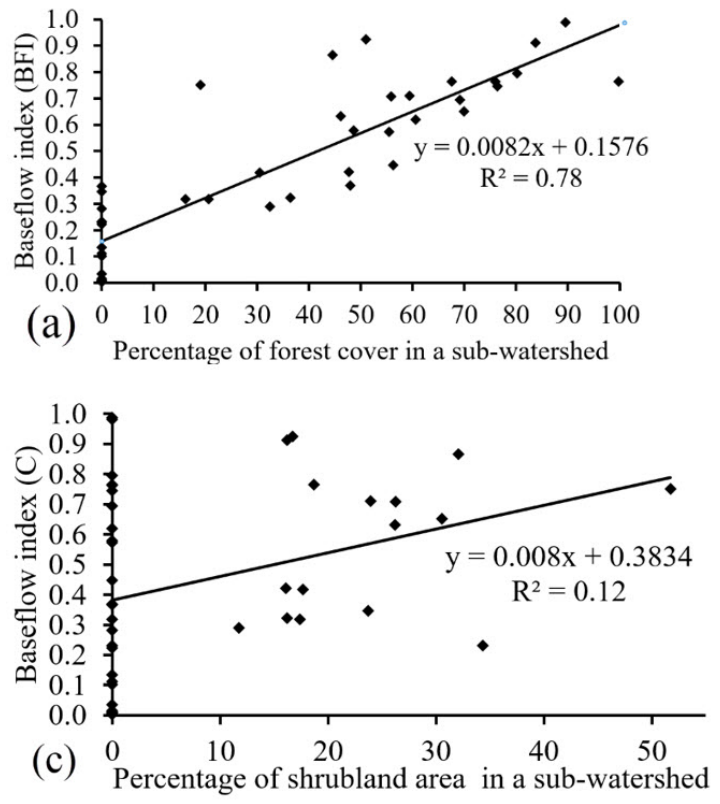

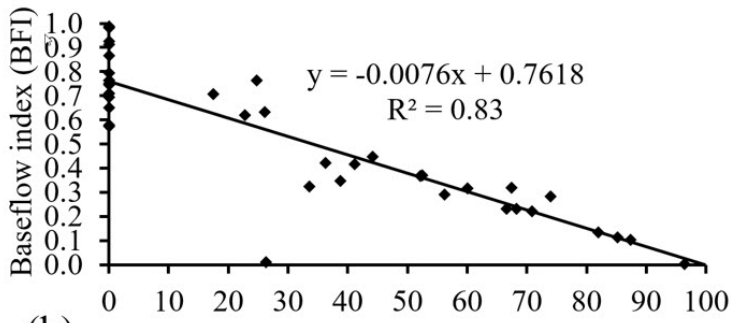

(b) Percentage of oil palm and rubber plantation cover in a sub-watershed

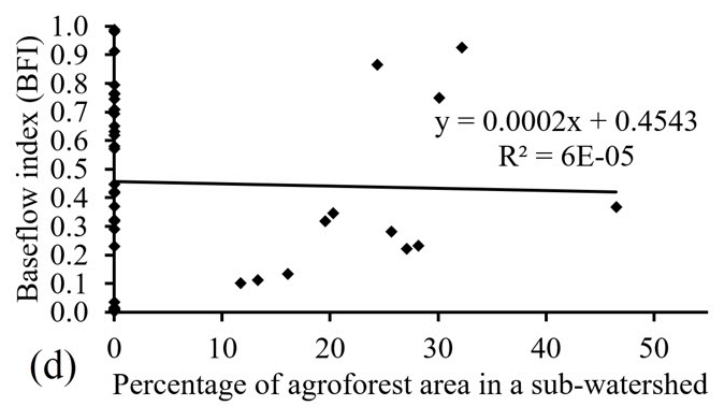

Figure 6. Association between simulated BFI values and the percentage of each land use type in a given sub-watershed.

\section{Results and discussion}

\subsection{Measured $C$ values}

The average $C$ value was based on nine individual rainfall events during the field experiment. The observed $C$ values that were measured during two small watershed experiments was 0.59 (Table 5). This value was comparable with the averaged simulated values of 0.60 for sub-watersheds with comparable proportions of land use type with those of the small watershed experiment (Table 6).

\subsection{SWAT model performance}

The sensitive parameters that were included in the calibration of the SWAT model are ranked in Table 7. Some of these parameters play an important role in controlling the initial abstraction of rainfall (e.g., CANMX), rainfall partitioning into surface runoff (e.g., CN2 and OV_N), and vertical movement of water through the soil (e.g., SOL_BD, SOL_K, and SOL_AWC).

A visual comparison of best-fit simulations and observed data is shown in Fig. 4, with NSE values of $0.80-0.88$ (calibration) and 0.84-0.85 (validation) and PBIAS values of -2.9 to 1.2 (calibration) and 7.0-11.9 (validation) for $\mathrm{BH}$ and MT watersheds, respectively. Based on the criterion proposed by Moriasi et al. (2007, 2015), the model performance was considered very good and satisfactory for calibration and validation, respectively.

\subsection{Simulated $C$ and BFI values and the proportion of land use types in a watershed}

The proportion of a particular land use type in a subwatershed was significantly correlated with $C$ and BFI values obtained from 48 data vectors (Table 4 ). $C$ values significantly decreased as the percentage of forest cover increased $\left(R^{2}=0.73 ; p<0.05\right.$; Fig. 5a) and significantly increased as the percentage of plantation cover increased $\left(R^{2}=0.74\right.$; $p<0.05$; Fig. 5b). Low infiltration capacity in oil palm and rubber plantations was the reason for higher $C$ values in the sub-watersheds with high proportions of plantation land use. There were no significant associations between $C$ values and any of the other land use types such as shrubland (Fig. 5c), agroforest (Fig. 5d), and dryland farming (data not shown). Some sub-watersheds had low $C$ values despite having low levels of forest cover (e.g., BH 19). This can be explained by the fact that BH 19 had no oil palm or rubber plantations but consisted of $52 \%$ of shrubland, which will have helped in reducing the $C$ value. Furthermore, some watersheds had $100 \%$ forest cover but a low BFI value (e.g., MT 23). This is the only sub-watershed in the MT watershed to have a high proportion of steeper slopes $(76 \%$ of the subwatershed), which will increase $C$ and decrease BFI. Among the 48 sub-watersheds we considered, only two had these slope characteristics.

The Ministry of Forestry of Indonesia considers $C$ values of $<0.35$ to be adequate for supporting the required ecosystem services of Indonesian watersheds (Ministry of Forestry Decree, 2013). Based on our findings, $\geq 30 \%$ forest cover (Fig. 5a) and $\leq 40 \%$ plantation cover (Fig. 5b) are required 
in a given sub-watershed with rapid expansion of plantation to achieve the desired $C$ value.

BFI values significantly increased as the percentage of forest cover increased ( $R^{2}=0.78 ; p<0.05$; Fig. 6a) and significantly decreased as the percentage of plantation cover increased $\left(R^{2}=0.83 ; p<0.05\right.$; Fig. $\left.6 \mathrm{~b}\right)$. BFI was not significantly related to any other land use types such as shrubland (Fig. 6c), agroforest (Fig. 6d), and dryland farming (data not shown). According to Neitsch et al. (2009), the SWAT model considers only shallow groundwater in stream flow simulation. Therefore, we expected that SWAT underestimated BFI values in our study area. To improve the performance of the SWAT model for deep groundwater flow (low flow) simulation, Pfannerstill et al. (2014) modified the groundwater module by splitting the active groundwater storage into a fast and a slow contributing aquifer. Similar studies that focused on modifications of the SWAT groundwater component to obtain improved baseflow and overall streamflow results have also been reported by Luo et al. (2012) and Wang and Brubaker (2015). Similar modifications are needed in the standard SWAT model in order to more accurately simulate the conditions such as those encountered in this study.

\subsection{Application of the research findings}

The conversion of tropical rainforest into oil palm and rubber plantations affects the local hydrological cycle by increasing ET, decreasing infiltration, decreasing low flow levels, and increasing flooding frequency. In Jambi Province, Indonesia, forested areas have been largely transformed into plantations, resulting in inhabitants experiencing water shortages during the dry season and dramatic increases in flooding frequency during the wet season. One way in which this problem could be mitigated is by maintaining an adequate proportion of forested and plantation areas in a particular watershed, but this raises the question about what the minimum percentage of forest area and the maximum proportion of plantation area in a watershed is that will allow the maintenance of adequate water flow regulation. This study is the first to describe the quantitative association between forest and plantation areas and the flow indicators $C$ and BFI; this understanding is required by spatial planners if they are to balance the ecology and socioeconomic functions of a landscape with the rapid expansion of plantation crops. In addition, our study provides data regarding how SWAT input parameters related to tropical plantations, such as oil palm and rubber, should be adjusted, particularly those that play an important role in controlling rainfall initial abstraction (e.g., CANMX), rainfall partitioning into surface runoffs (e.g., CN2, OV_N), and vertical movement of water through (e.g., SOL_BD, SOL_K, and SOL_AWC).

\section{Summary}

We found that ALPHA_BF, CN2, GW_DELAY, CANMX, SOL_BD, GWQMN, SOL_K, CH_N2, SOL_AWC, and OV_N were sensitive parameters in our model, some of which play an important role in controlling the initial abstraction of rainfall (e.g., CANMX), rainfall partitioning into surface runoff (e.g., CN2, OV_N), and vertical movement of water through the soil (e.g., SOL_BD, SOL_K, and SOL_AWC).

Overall, the SWAT model performance was strong, with NSE values of $0.80-0.88$ (calibration) and $0.80-0.85$ (validation) and PBIAS values of $-2.9-1.2$ (calibration) and 7.0-11.9 (validation). We found that the percentage of forest cover in a watershed was significantly negatively correlated with $C$ and positively correlated with BFI, whereas the percentage of rubber and oil palm plantation cover showed the opposite pattern. Finally, our findings suggest that a watershed should contain $\geq 30 \%$ forest cover and a maximum of $40 \%$ plantation cover for maintaining sustainable water flow regulation ecosystem services.

The quantitative association between forest cover and flow indicators, which was derived in this study, will help regional planners in determining the minimum proportion of forest cover that needs to be maintained to ensure effective water flow regulation in a watershed.

Data availability. The land use data are freely available for research purposes upon official request to the corresponding institutions: the rainfall and climate data can be obtained from the Meteorology and Geophysics Agency; the streamflow data of the macro watersheds can be obtained from the Ministry of Public Works; and the land use data can be obtained from the Regional Planning Office. The streamflow time series and rainfall records for the small watersheds and data for the resampled soil hydraulic conductivity, bulk density, available water content, and texture have been deposited by the first author at Bogor Agricultural University and in the EFForTS database (https://efforts-is.uni-goettingen.de).

Competing interests. The authors declare that they have no conflict of interest.

Special issue statement. This article is part of the special issue "Coupled terrestrial-aquatic approaches to watershed-scale water resource sustainability". It is not associated with a conference.

Acknowledgements. This study was performed in the framework of the joint Indonesian-German research project EFForTS-CRC 990 (http://www.uni-goettingen.de/crc990) and was funded by the Directorate General of Higher Education (DIKTI), Indonesia.

Edited by: Ann van Griensven

Reviewed by: two anonymous referees 


\section{References}

Abbaspour, K. C.: SWAT-CUP 2012: SWAT Calibration and Uncertainty Programs - A User Manual, 2012, Eawag-Swiss Federal Institute of Aquatic Science and Technology, 2015.

Adnan, N. A. and Atkinson, P. M.: Exploring the impact of climate and land use changes on streamflow trends in a monsoon catchment, Int. J. Climatol., 31, 815-831, 2011.

Afriyanti, D., Kroeze, C., and Saad, A.: Indonesia palm oil production without deforestation and peat conversion by 2050, Sci. Total. Environ., 557/558, 562-570, 2016.

Alemayehu, T., van Griensven, A., Woldegiorgis, B. T., and Bauwens, W.: An improved SWAT vegetation growth module and its evaluation for four tropical ecosystems, Hydrol. Earth Syst. Sci., 21,9, 4449-4467, https://doi.org/10.5194/hess21-4449-2017, 2017.

Allen, K., Corre, M., Tjoa, A., and Veldkamp, E.: Soil nitrogencycling response to conversion of lowland forests to oil palm and rubber plantations in Sumatra, Indonesia, PLoS One, 10, e0133325, https://doi.org/10.1371/journal.pone.0133325, 2015.

Arnold, J. G., Moriasi, D. N., Gassman, P. W., Abbaspour, K. C., White, M. J., Srinivasan, R., Santhi, R. C., Harmel, R. D., van Griensven, A., Van Liew, M. W., Kannan, N., and Jha, M. K.: SWAT: Model use, calibration, and validation, T. ASABE., 55, 1491-1508, 2012.

Babel, M. S., Shrestha, B., and Perret, S. R.: Hydrological impact of biofuel production: a case study of the Khlong Phlo Watershed in Thailand, Agric. Water. Manag., 101, 8-26, https://doi.org/10.1016/j.agwat.2011.08.019, 2011.

Banabas, M., Turner, M. A., Scotter, D. R., and Nelson, P. N.: Losses of nitrogen fertilizer under oil palm in Papua New Guinea: 1. Water balance, and nitrogen in soil solution and runoff, Aust. J. Soil Res., 46, 332-339, 2008.

Blume, T., Zehe, E., and Bronstert, A.: Rainfall-runoff response, event-based runoff coefficients and hydrograph separation, Hydrol. Sci. J., 52, https://doi.org/10.1623/hysj.52.5.843, 2007.

Bosch, J. M. and Hewlett, J. D.: A review of catchment experiments to determine the effect of vegetation changes on water yield and evapotranspiration, J. Hydrol., 55, 3-23, 1982.

Bressiani, D. D. A., Gasman, P., Fernades J. G., and Mediondo, E. M.: A review of Soil and Water Assessment Tool (SWAT) applications in Brazil: Challenges and prospects, IJABE, 8, 9-35, https://doi.org/10.3965/j.ijabe.20150803.1765, 2015.

Brown, A. E., Zhang, L., McMahon, T. A., Western, A. W., and Vertessy, R. A.: A review of paired catchment studies for determining changes in water yield resulting from alterations in vegetation, J. Hydrol., 310, 28-61, 2005.

Bruijnzeel, L. A.: (De)forestation and dry season flow in the tropics: a closer look, J. Trop. For. Sci., 1, 229-243, 1989.

Bruijnzeel, L. A.: Hydrology of moist tropical forests and effects of conversion: a state of knowledge review, UNESCO International Hydrological Programme, A publication of the Humid Tropics Programme, UNESCO, Paris, 1990.

Bruijnzeel, L. A.: Hydrological functions of tropical forests: not seeing the soil for the trees?, Agr. Ecosyst. Environ., 104, 185228, 2004.

Carlson, K. M., Curran, L. M., Ratnasari, D., Pittman, A. M., Soares-Filho, B. S., and Asner, G. P.: Committed carbon emissions, deforestation, and community land conversion from oil palm plantation expansion in West Kalimantan, Indonesia, Proc. Natl. Acad. Sci. USA, 109, 7559-7564, 2012.

Colchester, M., Jiwan, N., Andiko, Sirait, M., Firdaus, A. Y., Surambo, A., and Pane, H.: Promised Land: Palm Oil and Land Acquisition in Indonesia - Implications for Local Communities and Indigenous Peoples, ISBN: 979-15188-0-7, Forest Peoples Programme, Perkumpulan Sawit Watch, HuMA and the World Agroforestry Centre, Bogor, Indonesia, 2006.

Comte, I., Colin, F., Whalen, J. K., Gruenberger, O., and Caliman, J. P.: Agricultural practices in oil palm plantations and their impact on hydrological changes, nutrient fluxes and water quality in Indonesia: a review, Adv. Agron., 116, 71-124, 2012.

Dietz, J., Hölscher, D., and Leuschner, C.: Rainfall partitioning in relation to forest structure in differently managed montane forest stands in Central Sulawesi, Indonesia For. Ecol. Manage., 237, 170-178, 2006.

Dislich, C., Faust, H., Kisel, Y., Knohl, A., Otten, F., Meyer. K., Pe'er, G., Salecker, J., Steinebach, S., Tarigan, S., Tölle, M., and Wiegand, K.: A review of the ecosystem functions in oil palm plantations, using forests as a reference system, Biol. Rev., 92, 1539-1569, https://doi.org/10.1111/brv.12295, 2017.

Ditjenbun: Indonesian plantation statistics, Directorate General for Plantations, Ministry of Agriculture Indonesia, 2015.

Douglas-Mankin, K. R., Srinivasan, R., and Arnold, A. J.: Soil and Water Assessment Tool (SWAT) model: Current developments and applications, T. ASABE, 53, 1423-1431, https://doi.org/10.13031/2013.34915, 2010.

Drescher, J., Rembold, K., Allen, K., Beckschäfer, P., Buchori, D., Clough, Y., Faust, H., Fauzi, A. M., Gunawan, D., Hertel, D., Irawan, B., Jaya, I. N. S., Klarner, B., Kleinn, C., Knohl, A., Kotowska, M. M., Krashevska, V., Krishna, V., Leuschner, C., Lorenz, W., Meijide, A., Melati, D., Nomura, M., Pérez-Cruzado, C., Qaim, M., Siregar, I. Z., Steinebach, S., Tjoa, A., Tscharntke, T., Wick, B., Wiegand, K., Kreft, H., and Scheu, S.: Ecological and socioeconomic functions across tropical land-use systems after rainforest conversion, Phil. T. R. Soc. B, 371, 20150275, https://doi.org/10.1098/rstb.2015.0275, 2016.

Ellison, D., Morris, C. E., Locatelli, B., Sheil, D., Cohen, J., Murdiyarso, D., Gutierrez, V., van Noordwijk. M., Creed, I. F., Pokorny, J., Gaveau, D., Spracklen, D. V., Tobella, A. B., Ilstedt, U., Teuling, A. J., Gebrehiwot, S. G., Sands, D. C., Muys, B., Verbist, B., Springgay, E., Sugandi, G., Sullivan, C. A.: Trees, forests and water: Cool insights for a hot world, Glob. Environ. Change, 43, 51-61, https://doi.org/10.1016/j.gloenvcha.2017.01.002, 2017.

Fan, Y., Roupsard, O., Bernoux, M., Le Maire, G., Panferov, O., Kotowska, M. M., and Knohl, A.: A sub-canopy structure for simulating oil palm in the Community Land Model (CLM-Palm): phenology, allocation and yield, Geosci. Model Dev., 8, 37853800, https://doi.org/10.5194/gmd-8-3785-2015, 2015.

Fitzherbert, E. B., Struebig, M. J., Morel, A., Danielsen, F., Brühl, C. A., Donald, P. F., and Phalan, B.: How will oil palm expansion affect biodiversity?, Trends. Ecol. Evol., 23, 538-545, 2008.

Fox, J., Vogler, J. B., Sen, O. L., Giambelluca, T. W., and Ziegler, A. D.: Simulating land-cover change in Montane mainland Southeast Asia, Environ. Manage., 49, 968-979, https://doi.org/10.1007/s00267-012-9828-3, 2012.

Gassman, P. W., Reyes, M. R., Green, C. H., and Arnold, J. G.: The soil and water assessment tool: historical development, applica- 
tions, and future research direction, Amer. Soc. Agric. Bio. Eng., 50, 1211-1250, 2007.

Gassman, P. W., Sadeghi, A. M., and Srinivasan, R.: Applications of the SWAT Model Special Section: Overview and Insights, J. Environ. Qual., 43, 1-8, https://doi.org/10.2134/jeq2013.11.0466, 2014.

Gatto, M., Wollni, M., Asnawi, R., and Qaim, M.: Oil palm boom, contract farming, and rural economic development: village-level evidence from Indonesia, World Dev., 95, 127-140, 2017.

Guillaume, T., Damris, M., and Kuzyakov, Y.: Losses of soil carbon by converting tropical forest to plantations: erosion and decomposition estimated by $\delta^{13} \mathrm{C}$, Glob. Chang. Biol., 21, 3548-3560, 2015.

Guillaume, T., Holtkamp, A. M., Damris, M., Brümmer, B., and Kuzyakov, Y.: Soil degradation in oil palm and rubber plantations under land resource scarcity, Agr. Ecosyst. Environ., 232, 110$118,2016$.

Guo, J., Su, X., Singh, V. P., and Jin, J.: Impacts of climate and land use/cover change on streamflow using SWAT and a separation method for the Xiying River basin in Northwestern China, Water, 8, 1-14, https://doi.org/10.3390/w8050192, 2016.

Gupta, H. V., Sorooshian, S., and Yapo, P. O.: Status of automatic calibration for hydrologic models: Comparison with multilevel expert calibration, J. Hydrol. Eng., 4, 135-143, 1999.

Hardanto, A., Röll, A., Niu, F., and Meijide, A.: Oil palm and rubber tree water use patterns - effects of topography and flooding, Front. Plant. Sci., 8, 1-12, 2017.

Hassler, E., Corre, M. D., Kurniawan, S., and Veldkamp, E.: Soil nitrogen oxide fluxes from lowland forests converted to smallholder rubber and oil palm plantations in Sumatra, Indonesia, Biogeosciences, 14, 2781-2798, https://doi.org/10.5194/bg-142781-2017, 2017.

Hewlett, J. D. and Hibbert, A. R.: Factors affecting response of small watersheds to precipitation in humid areas, in: Forest Hydrology, edited by: Sopper, W. E. and Lull, H. W., Pergamon Press, New York, 1967.

Khoi, D. N. and Suetsugi, T.: Impact of climate and land-use changes on hydrological processes and sediment yield - a case study of the Be River catchment, Vietnam, Hydrol. Sci. J., 59, 1095-1108, https://doi.org/10.1080/02626667.2013.819433, 2014.

Koh, L. P. and Wilcove, D. S.: Is oil palm agriculture really destroying tropical biodiversity?, Conserv. Lett., 1, 60-64, 2008.

Krashevska, V., Klarner, B., Widyastuti, R., Maraun, M., and Scheu, S.: Impact of tropical lowland rainforest conversion into rubber and oil palm plantations on soil microbial communities, Biol. Fertil. Soil., 51, 697-705, 2015.

Kumagai, T., Saitoh, T. M., Sato, Y., Takahashi, H., Manfroi, O. J., Morooka, T., Kuraji, K., Suzuki, M., Yasunari, T., and Komatsu, H.: Annual water balance and seasonality of evapotranspiration in a Bornean tropical rainforest, Agr. Forest Meteorol., 128, 8192, 2005.

Lele, S.: Watershed services of tropical forests: from hydrology to economic valuation to integrated analysis, Curr. Opin. Env. Sust., 1, 148-155, 2009.

Le Maitre, D. C., Kotzee, I. M., and O'Farrell, P. J.: Impacts of landcover change on the water flow regulation ecosystem service: Invasive alien plants, fire and their policy implications, Land Use Policy, 36, 171-181, 2014.
Luo, Y., Arnold, J., Allen, P., and Chen, X.: Baseflow simulation using SWAT model in an inland river basin in Tianshan Mountains, Northwest China, Hydrol. Earth Syst. Sci., 16, 1259-1267, https://doi.org/10.5194/hess-16-1259-2012, 2012.

Marhaento, H., Booij, M. J., Rientjes, T. H. M., and Hoekstra, A. Y.: Attribution of changes in the water balance of a tropical catchment to land use change using the SWAT model, Hydrol. Process., 31, 2029-2040, https://doi.org/10.1002/hyp.11167, 2017.

Meijide, A., Röll, A., Fan, Y., Herbst, M., Niu, F., Tiedemann, F., June, T., Rauf, A., Hölscher, D., and Knohl, A.: Controls of water and energy fluxes in oil palm plantations: environmental variables and oil palm age, Agr. Forest Meteorol., 239, 71-85, 2017.

Merten, J., Röll, A., Guillaume, T., Meijide, A., Tarigan, S., Agusta, H., Dislich, C., Dittrich, C., Faust, H., Gunawan, D., and Hein, J.: Water scarcity and oil palm expansion: social views and environmental processes, Ecol. Soc., 21, 5-16, 2016.

Ministry of Forestry Decree - Permenhut/Menhut-V/2013.: Criteria for watershed classification (Kriteria Penetapan Klassifikasi Daerah Aliran Sungai), Ministry of Forestry, Republic of Indonesia, 2013.

Moriasi, D. N., Arnold, J. G., van Liew, M. W., Binger, R. L. Harmel, R. D., and Veith, T.: Model evaluation guidelines for systematic quantification of accuracy in watershed simulations, T. ASABE, 50, 885-900, 2007.

Moriasi, D. N., Gitau, M. W., Pai, N., and Daggupati, P.: Hydrologic and water quality models: performance measures and evaluation criteria, T. ASABE, 58, 1763-1785, https://doi.org/10.13031/trans.58.10715, 2015.

Mukherjee, I. and Sovacool, B. K.: Palm oil-based biofuels and sustainability in southeast Asia: a review of Indonesia, Malaysia, and Thailand, Renew. Sust. Energ. Rev., 37, 1-12, https://doi.org/10.1016/j.rser.2014.05.001, 2014.

Mwangi, H. M., Julich, S., Pati, S. D., McDonald, M. A., and Feger, K. H.: Relative contribution of land use change and climate variability on discharge of upper Mara River, Kenya, J. Hydrol., 5, 244-260, 2016.

Nash, J. and Sutcliffe, J. V.: River flow forecasting through conceptual models, 1, A discussion of principles, J. Hydrol., 10, 282290, 1970.

Neitsch, S. L., Arnold, S. G., Kiniry, J. R., and Williams, J. R.: Soil and water assessment tool theoretical documentation, Version 2009, Texas Water Resources Institute Technical Report No. 406, Texas A\&M University System, College Station, Texas, 1$8,2011$.

Pfannerstill, M., Guse, B., and Fohrer, N.: A multi-storage groundwater concept for the swat model to emphasize non- linear groundwater dynamics in lowland catchments, Hydrol. Process., 28, 5599-5612, https://doi.org/10.1002/hyp.10062, 2014.

Pransiska, Y., Triadiati, T., Tjitrosoedirjo, S., Hertel, D., and Kotowska, M. M.: Forest conversion impacts on the fine and coarse root system, and soil organic matter in tropical lowlands of Sumatera (Indonesia), Forest Ecol. Manag., 379, 288-298, 2016.

Rientjes, T. H. M., Haile, A. T., Kebede, E., Mannaerts, C. M. M., Habib, E., and Steenhuis, T. S.: Changes in land cover, rainfall and stream flow in Upper Gilgel Abbay catchment, Blue Nile basin - Ethiopia, Hydrol. Earth Syst. Sci., 15, 1979-1989, https://doi.org/10.5194/hess-15-1979-2011, 2011.

Röll, A., Niu, F., Meijide, A., Hardanto, A., Hendrayanto, Knohl, A., and Hölscher, D.: Transpiration in an oil palm land- 
scape: effects of palm age, Biogeosciences, 12, 5619-5633, https://doi.org/10.5194/bg-12-5619-2015, 2015.

Setiadi,B., Diwyanto, K., Puastuti, W., Mahendri, I. G. A. P., and Tiesnamurti, B.: Peta Potensi dan Sebaran Areal Perkebunan Kelapa Sawit di Indonesia, Pusat Penelitian dan Pengembangan Peternakan, BadanLitbang Pertanian, Kementerian Pertanian (Area distribution of oil palm plantation in Indonesia, Center for Research and Development, Ministry of Agriculture Indonesia), ISBN 978-602-8475-45-7, 2011.

Sterling, S. M., Ducharne, A., and Polcher, J.: The impact of global land cover change on the terrestrial water cycle, Nature Climate Change, 3, 385-390, https://doi.org/10.1038/nclimate1690, 2012.

Strauch, M. and Volk, M.: SWAT plant growth modification for improved modeling of perennial vegetation in the tropics, Ecol. Modell., 269, 98-112, https://doi.org/10.1016/j.ecolmodel.2013.08.013, 2013.

Sunarti, Sinukaban, N., Sanim, B., and Tarigan, S. D.: Forest conversion to rubber and oil palm plantation and its effect on runoff and soil erosion in Batang Pelepat watershed, Jambi, J. Tanah Tropika, Vol. 13. No.3, ISSN 0852-257X, Lampung, 2008.

Tarigan, S. D.: Land cover change and its impact on flooding frequency of Batanghari Watershed, Jambi Province, Indonesia, Procedia, Environ. Sci., 33, 386-392, 2016a.

Tarigan, S. D., Wiegand, K., Dislich, C., Slamet, B., Heinonen, J., and Meyer K.: Mitigation options for improving the ecosystem function of water flow regulation in a watershed with rapid expansion of oil palm plantations, Sustainability of Water Quality and Ecology, 8, 4-13, $2016 \mathrm{~b}$.

Tuppad, P., Douglas-Mankin, K. R., Lee, T., Srinivasan, R., and Arnold, J. G.: Soil and Water Assessment Tool (SWAT) hydrologic/water quality model: Extended capability and wider adoption, T. ASABE, 54, 1677-1684, https://doi.org/10.13031/2013.34915, 2011.

Van der Laan, C., Wicke, B., Verweij, P. A., and Faaij, A. P. C.: Mitigation of unwanted direct and indirect land-use change-an integrated approach illustrated for palm oil, pulpwood, rubber and rice production in North and East Kalimantan, Indonesia, GCB Bioenergy, 9, 429-444, https://doi.org/10.1111/gcbb.12353, 2016.

Van der Molen, M. K., Dolman, A. J., Waterloo, M. J., and Bruijnzeel, L. A.: Climate is affected more by maritime than by continental land use change: a multiple scale analysis, Global Planet. Change, 54, 128-149, 2006.

Van Griensven, A., Meixner, T., Grunwald, S., Bishop, T., Diluzio, M., and Srinivasan, R. A.: Global sensitivity analysis tool for the parameters of multi-variable catchment models, J. Hydrol., 324, 10-23, 2006.
Van Griensven, A., Maharjan, S., and Alemayehu, T.: Improved simulation of evapotranspiration for land use and climate change impact analysis at catchment scale, International Environmental Modelling and Software Society (iEMSs) 7th International Congress on Environmental Modelling and Software, 2014.

Vigerstol, K. L., Aukema, J. E.: A comparison of tools for modeling freshwater ecosystem services, J. Environ. Manage., 92, 24032409, 2011.

Vijay, V., Pimm, S. L., Jenkins, C. N., and Smith, S. J.: The impacts of oil palm on recent deforestation and biodiversity loss, PLoS One, 11, e0159668, https://doi.org/10.1371/journal.pone.0159668, 2016.

Wang, Y. and Brubaker, K.: Implementing a nonlinear groundwater module in the soil and water assessment tool (SWAT), Hydrol. Process., 28, 3388-3403, https://doi.org/10.1002/hyp.9893, 2014

Wangpimool, W., Pongput, K., Tangtham, N., Prachansri, S., and Gassman, P. W.: The impact of para rubber expansion on streamflow and other water balance components of the Nam Loei River Basin, Thailand, Water, 9, 1-20, https://doi.org/10.3390/w9010001, 2017.

Wicke, B., Sikkema, R., Dornburg, V., and Faaij, A.: Exploring land use changes and the role of palm oil production in Indonesia and Malaysia, Land Use Policy, 28, 193-206, 2011.

Wilcove, D. S. and Koh, L. P.: Addressing the threats to biodiversity from oil-palm agriculture, Biodivers. Conserv., 19, 999-1007, 2010.

Xu, X., Yang D., Yang, H., and Lei, H.: Attribution analysis based on the Budyko hypothesis for detecting the dominant cause of runoff decline in Haihe basin, J. Hydrol., 510, 530-540, 2014.

Yusop, Z., Chan, C. H., and Katimon, A.: Runoff characteristics and application of HEC-HMS for modelling stormflow hydrograph in an oil palm catchment, Water Sci. Technol., 56, 41-48, 2007.

Zhang, L., Nan, Z., Xu, Y., and Li, S.: Hydrological impacts of land use change and climate variability in the headwater region of the Heihe river basin, Northwest China, PLoS One, 11, e0158394, https://doi.org/10.1371/journal.pone.0158394, 2016.

Ziegler, A. D., Fox, J. M., and Xu, J.: The rubber juggernaut, Science, 324, 1024-1025, https://doi.org/10.1126/science.1173833, 2009.

Ziegler, A. D., Fox, J. M., Webb, E. L., Padoch, C., Leisz, S. J., Cramb, R. A., Mertz, O., Bruun, T. B., and Vien, T. D.: Recognizing contemporary roles of swidden agriculture in transforming landscapes of Southeast Asia, Conserv. Biol., 25, 846-848, 2011. 